\title{
The Usage of Some Names of Plants
}

\author{
Prof. Ass. Dr Haredin Xhaferi \\ "Aleksander Moisiu" University \\ Durres, Albania \\ haredin.xhaferi@gmail.com
}

Doi:10.5901/mjss.2013.v3n2p367

\begin{abstract}
The lexicon of any language consists of units with a closed structure (words) and units with a phrase structure, that by the meaning are equivalent to the word. The latter are used with the words, without substituting them. This category also includes names of plants with a phrase structure. These structures have named different plants, on the basis of their specific characteristics and features. They constitute a special category that lies in the word boundaries and the phraseological phrase as well. This article will discuss this phenomenon. They are units consisting of two members, which are same or different lexico - grammatical categories. One of the elements in these structures has lost its basic meaning and to the whole unit is given another meaning. This paper treats the structures with nouns, that are interdependent. The second nouns is in the accusative case or in the indefinite resultative case. Today's trend of these structures is providing them as a single word. This is noticed even in the explanatory dicitionaries of albanian language, in which these units are reflected in two forms: as words and as phrases. These phrases are of phraseological character, but are included in terminologic phrases, that stand in between free phrases and phraseological ones. The phenomenan of providing one word is more possible in the structures whose second noun is in the accusative case and between their members are set similarity relationships. In these structures the use of the second noun in the indefinite resultative case or in the definite genitive is not right. The units whose second noun is in the resultative case, can be provided as one word, due to the semantic relations between them (of interdependence, of belonging to each other) and the use of the indefinite resultative case flection.
\end{abstract}

Subject to this article shall be made in the names of plants that have the phrase structure. The usage of these structures in addition units one- words, is a phenomenon known in Albanian and in many other languages. English language phrase in formations of structure are a continuous process, which is based on real opportunities vocabulary system for creating lexical semantic units(Thomai, J. 1986), potential abilities in English speech to be developed by the semantic as well as links and different combinations during usage.

Names of phrase structure are a special category of the Albanian vocabulary. These names along with the wording, not words represent actual element, to which the word life reflected in the plans of the various measures(Kostallari, A.1972). Studies on these purely linguistic units in Albanian missing.

The formation of these names is a result of the classification of plants in different species hybrids. In some cases forming the basis of their monosyllabic term (Duro, A. 2001). They are generally located on a single concept of thorough and semantically express a single notion, label a plant and in most cases have one-word synonyms.

These names stand out among word - structure logical phrases unit and have their parallels in other areas of special and general language. They are consistent with heaps of attributive and racial definition. Although usually consist of two members, they are a single unit-semantic lexicon. We distinguished element of their structure and the main determinant element.

From the lexicon and grammatical value of these designations represent members of different groups.

In this short introduction will be treated denominations formed by two names.

The structure of one of these elements is missing rationale and is generally understandable unit. This feature provides him with idioms(Kostallari, A.). 
J. Thomai(1975) declares that such names, set on the figurative usage of the other member, has included sustainable platoons initially logical phrases. Subsequently changed his stance and ruled by linguistic phraseology. Denominations compound - words with member name + name he treats as a type of semi-open structure: in prominent forms as word and phrase in non-prominent forms as: barpeshkun and bar peshku, and çajmalin and çaj mali, gjeldetin and gjel deti, lulediellin and lule dielli(Thomai, I.1995). etc. These words were still missing non-prominent forms topic that does not bend in non-prominent forms singular as with other words such as: bregdet, fleterrufe, etc..

Some language structures used in general or in some specific areas, such as the author admits platoons stable, but not the type phraseological.

What distinguishes the stable phrases not logical phrases from sustainable logical phrases phrases, grammatical restriction is figures and the same(Duro, A.). Names of plants with the phrase included in the group structure of terminological sustainable phrases. They mark through sustainable relationships constituent elements a particular notion, conceived of as such. These were based phrases sustainable relationship between plants and features, and whom their properties, the villas are reflected in the phrase and as highlighted above, in some cases they are expressed by a single word or made up front.

Terminology phrases stand between phrases and logical phrases free. A. Duro emphasizes that these phrases may differ in both their components etc..

J. Thomai noticed that denominations of non-simple to plants out in the second member of non-prominent forms and can not be used in either the amount prominent forms while denominations of commonly used animal world in prominent forms and can not be used in non-prominent forms(J. Thomai,).

In reality there are many plants that are known by the same name and the use of their names in plural is necessary. From the observations, it results that the names of plants with the phrase structure are different types and degree of change its members is different.

The first name to denominations formed by two names can also be used in the form of outstanding, in both numbers in each case. Name of the second set denominations according to similarity in names can be used to non-prominent forms or genitive. So denomination speaker uses lule shqiponje uses lule shqiponje, lulja shqiponje, lulen shqiponje, lulet shqiponje lulen e shqiponjes, lulet e shqiponjes etc... Such are: bar preshi (bari presh, barin presh, barerat presh), bar fieri (bari fier, barin fier, barerat fier), bar qepe (bari qepe, barin qepe, barerat qepe), lule vathi (lulja vath, lulen vath, lulet vath) etc. at the second name which can be used both in genitive (bari i preshit, bari i fierit, bari i qepes etc.) as with denominations of non-simple established on the basis of belonging ( bar $i$ shkembit, bar i plehut, bar i zemres, bar i reumatizmes etc.).

We put names based on similarity figures sets the figurative meaning (comparison). So bar fieri "Herbage that is as fern." etc. This gives explanation of K. Cipo for designation composite lule-laker: "A flower that sprouts is..."( Cipo, K.).

In this case form comes the second name even in some phrase structures in general language, whose members are in a attributive or appositive relationship as: dhomë, shpellë, qytet hero, shtëpi muze, vinc kulle, njeri gorille etc. to which the first is variable.

The usage of the second name in the genitive case in denominations set to the similarities is not acceptable because there are no belongings. So cherry blossom means "belonging cherry flowers ..." while realistically that designation has also a special plant that has similarities with cherry blossom. In this case create difficulties in communication beyond a certain situation, when the plant is not present, there after parallel phrase: cherry blossom.

Second element label non-similar located on the basis of genitive used in affiliation. $\mathrm{t}$ is used bar zgjebeje and bari i zgjebes, bar shkembi and bari i shkembit, bar plehu and bari i plehut bar zemre and bari i zemres, bar reumatizme and bari i reumatismes etc.

The usage of the second name of genitive of the group label is justified because in the Albanian language as genitive case rule distinguished semantically substituted by the consequential(Buxheli, L. 2007). Gender or name consequential carries internal semantic role to possessive or origin. The second name labels similarity with respect to which the internal semantic relations are neither possessive nor source may not be used or genitive but consequential names of non-prominent.

These designations and desigations with the second member "an adjective" generally have a high degree one-word, by neutralizing the flame cases content (Thomai, I.). May be used: barpresh-i, barsahat-i, lulelaker - $a$, 
luleshpender - a, ahbardh/e-i, ahzi-u, lakerverdh/e-a, gjembbardh/e-i gjembzi-u, ferrebardh/e- $a$, ferrezez/e-a, murrizkuq-i, etc. instead of: bar preshi, bar sahati, lule lakre, lule shpendre, ah i bardhe, ah $i$ zi, laker e verdhe, gjemb i bardhe, gjemb i zi, ferre e bardhe, ferre e zeze, murriz i kuq etc.

Greater opportunity to one-word have seen denominations that have been adjective usage (denominations with the first element name of a body part plants, the animal, the name of an object or something else, such as lule gishti, lule ngjitese, lule qumeshtore, gjuhe lope, bisht kali, gjurme mushke etc..) such use does not conflict with the laws of nature language. Through grammatical bent configuration possible that this category label deal as I finished one -word process. The labels one - word with two names in many cases avoid misunderstandings during lecturing and helping their use in different numbers of case.

Even descriptors of these designations have masculine or feminine, this barpresh, ky baririq, kjo lulelaker, ky ahbardhe, kjo ferrebardhe etc.. Subgroup denominations of the second label name + name, unlike the above denominations, serve as the transition between use cases as phrase and not a single word.(Buxheli, L.1994)

They receive descriptors match in gender only with their first element, so the designations are semi-open structure. Saving the case content of the flame prevents non-prominent one-word process. These designations are grammarian with the full structure and bending thy full paradigm.

The one-word scale of these labels is poor, but it is not impossible. This is also because of general language such names exist in a closed structure, such as phrase etc.. Non-simple denominations, as we have noted previously, express a single notion, but are not closed structure. They are likely to go one-word structures (composites).

Plenty of domestic and foreign linguists agree on the basis of composite phrases. K.Brugman claims that have composite source of phrases, while A. Maillet and J. Vendryes has come to accept that the composition of the attachment. (K. Brugman 1900) \&( Maillet 1948)

G. Weigand composite accepts as authentic phrases formed from the names of non-promnent name + name in the, consequential type ve - rose, kelysh-macesh etc.. (Weigand, G. 1913) can without making the distinction between word and speech composed. Such consider these phrases and K. Cipo. Both these authors depart from the requirement that the phrase forms a single notion, regardless of compound the grammatical form, as words with a closed structure.

A.Kostallari to accept these phrases "... two notions, of which the second defines the first, without being merged with the determinant as to prescribe in a single composite notion, as happens with words composed ..."

K. Cipo(1949) also includes composite structures decisive-type lule-laker (with egg) which J. Thomai cites for one-word high level, despite the use of phrases still alive parallel, as dite pune, nusja e lales etc.. (Thomai, J.)

Crossing the phenomenon of phrases in composite A. Kostallari accept its ongoing transition process of attachment of. compound. As we pronounced elsewhere, non-simple denominations of plants and animals in any of the dialect used in two forms: in the form of syntactic combinations and composites(Xhaferri, H. 2005). Even FGJSSH a great number of these labels are given as phrase and composite, for example.: lule bore dhe lulebore, lule breshke dhe lulebreshke, lule deleje dhe luledele, lule filxhani dhe lulefilxhan, lule kadifeje dhe lulekadife, lule kembore dhe lulekembore etc. A few of them are shown only as a composite. For example: lulefasule, lulegojë, lulegrerëz, lulekaçe, lulekëmbëpulë, lulekupë.

For this it is necessary to find any other form of designation. As example. luledielli said lulediellez-a or any other form. In FGJSSH these designations are not reflected as single word, but the ending of that non-prominent in consequential.The second element: luledielli, (page 102), panxharsheqeri (page 1349) while naming luledim/ër-ri (page 1022) is not reflected this endings.

Terminology phrases related to the plant world have a special nature in comparison with phrases terminology to other areas. We say this because most of them are built on the figurative use of constituent elements. It is for this reason that a part of them as previously noted, J. Thomai has included the logical phrases sustainable phrases and explanatory dictionaries after they are placed logical phrases units. Despite this, it should be said that many of them in these dictionaries are reflected as a separate unit. Such designations appear those who have passed on fully scorer and independent unit, for example. Lulecimk/ë-a; lulefasul/e-ja, lulekaç/eja, lulegoj/ë- $a$ etc. Denominations phrases that are units of half uniform linguistic elements are shown as dependent on the word representative example of pishë- pishë e butë, pishë e zezë, pishë deti, pishë e egër, pishë e kuqe etc. 
Two membered phrases, that do not only belong to plant's lexicon, when between their members exist similarity relationships, must be reflected only in one form: with only one word.

In explanatory dictionaries many plant's designations when presented as phrases, set as supplementary and illustratory material while when presented with one word structure, used as the title word. So for shkoza name given material as: shkozë e bardhë, shkozë e zezë, while composite shkozëbardhë, shkozëzezë are put as title words. In both cases (composite and phrase) expresses only one notion.

When denominations have many different semantic components may be reflected as a separate units for eg: ah i bardhë, ah i zi, gjemb i bardhë, gjemb i zi. etj.

Names of plants with the phrase structure occupy a considerable place in the Albanian explanatory and multilingual dictionaries. Work for their the accuracy and right use is really necessary because botanic is the science that is taught since elementary school. The Unification and specification of terms of this field and other users the opportunity to know better deeper the notions that these term phrases express .

Today the compilation of an explanatory dictionary with clear and unified terms for this area of science, which will help in determining the exact meaning of the designations as well as their right usage.

\section{Bibliography}

Brugman, K. (1900), Uber das Wesen der sog, Wertzusammensetzung, Leipzig,

Buxheli, L. (2007) Modelet e caktimit rasor në gjuhën e sotme shqipe

Cipo, K. Rreth disa kompozitave, Studime mbi leksikun .....Gramatika e gjuhës shqipe, II, 1995

Duro, A. Terminologjia si sistem, 2001,

Gramatika e gjuhës shqipe, II, 1995,

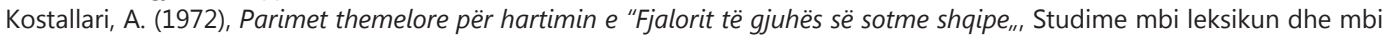
formimin e fjalëve në gjuhën shqipe, II, f. 37.

Kostallari A., Mbi disa veçori të fjalës së përbërë në gjuhën shqipe, Studime mbi leksikun

Maillet, A. - J. Vendryes, Traité de Grammaire comparée des langues classiques, 2e éd., Paris, 1948, f. 423 - 424.

Thomai, J. Çështje të leksikut potencial në gjuhën shqipe, Gjuha jonë, 2, 1986,

Thomai, J. Frazeologjizma emërorë dhe mbiemërorë në gjuhën shqipe, SF, 4, 1975,

Thomai, J. Mbi kufijtë e fjalës në gjuhën shqipe dhe disa çështje të drejtshkrimit të saj, SF, 1, 1973,

Thomai, J. Çështje të frazeologjisë në gjuhën shqipe, 1981,

Weigand, G. Albanesische Grammatik im südgegischen Dialekt, Leipzig, 1913,

Xhaferi, H. Emërtime të përbëra dhe të përngjitura në leksikun dialektor të botës bimore dhe shtazore, Kërkime universitare, Buletin i Universitetit “E. Çabej „, 11, 2005, 